\title{
OLHARES SUL-AMERICANOS SOBRE AS RELAÇÕES ENTRE FILOSOFIA E EDUCAÇÃO
}

Uma revista. Revista parece ser o substantivo do verbo revistar, que por sua vez significa examinar, buscar, passar a vista novamente. Re-olhar, colocar outro olhar. Talvez o maior objetivo desta nossa revista seja passar outros olhares, revistar examinando as relações entre filosofia e educação.

E que outros olhares são estes? São os olhares da América do Sul. Aqui o mapa não aparece como um limite, como uma proibição de outros olhares. Mas como uma escolha, politicamente engajada, de olhares que parecem próximos, mas pouco articulados e ainda assim interessantes. Estamos, ao convocar a América do Sul para esse revistar as interfaces entre filosofia e educação, buscando olhares diferentes, outros olhares, olhares críticos, interrogadores. Olhares que ventilem as relações já estabelecidas e gastas entre o fazer educacional e o fazer filosófico.

Pensamos que os olhares sul-americanos têm muito a contribuir para uma tarefa de re-estruturar as possibilidades de encontro e desencontro entre educação e filosofia.

O mapa da América do Sul longe de ser um limite é o convite para o pensar. Pensemos, pois, estas relações; lancemos outros olhares...

Este é o primeiro número. Uma parte interessante dele, entre outras partes interessantes, é o dossier que reúne os trabalhos apresentados no III Fórum CentroOeste sobre o Ensino de Filosofia, que está pensando os aspectos políticos, educacionais e filosóficos do ensino de filosofia. Eis um bom começo para multiplicar olhares sobre as relações entre filosofia e educação.

wanderson flor do nascimento editor 